\title{
Mode of Action and Specificity of Bacillus thuringiensis Toxins in the Control of Caterpillars and Stink Bugs in Soybean Culture
}

\author{
Rogério Schünemann, Neiva Knaak, and Lidia Mariana Fiuza \\ Programa de Pós-Graduação em Biologia-Laboratório de Microbiologia e Toxicologia, Centro de Ciências da Saúde, \\ Universidade do Vale do Rio dos Sinos, Avenida Unisinos, 950, 93022-000 São Leopoldo, RS, Brazil
}

Correspondence should be addressed to Neiva Knaak; neivaknaak@gmail.com

Received 23 September 2013; Accepted 26 November 2013; Published 20 January 2014

Academic Editors: A. Hamood and A. Netrusov

Copyright (C) 2014 Rogério Schünemann et al. This is an open access article distributed under the Creative Commons Attribution License, which permits unrestricted use, distribution, and reproduction in any medium, provided the original work is properly cited.

\begin{abstract}
The bacterium Bacillus thuringiensis (Bt) produces delta-endotoxins that possess toxic properties and can be used as biopesticides, as well as a source of genes for the construction of transgenic plants resistant to insects. In Brazil, the introduction of $B t$ soybean with insecticidal properties to the velvetbean caterpillar, the main insect pest of soybean, has been seen a promising tool in the management of these agroecosystems. However, the increase in stink bug populations in this culture, in various regions of the country, which are not susceptible to the existing genetically modified plants, requires application of chemicals that damage the environment. Little is known about the actual toxicity of $B t$ to Hemiptera, since these insects present sucking mouthparts, which hamper toxicity assays with artificial diets containing toxins of this bacterium. In recent studies of cytotoxicity with the gut of different hemipterans, susceptibility in the mechanism of action of delta-endotoxins has been demonstrated, which can generate promising subsidies for the control of these insect pests in soybean. This paper aims to review the studies related to the selection, application and mode of action of $B t$ in the biological control of the major pest of soybean, Anticarsia gemmatalis, and an analysis of advances in research on the use of $B t$ for control hemipterans.
\end{abstract}

\section{Introduction}

Soybean, Glycine $\max (\mathrm{L}$.$) , is the largest agricultural com-$ modity of economic importance in Brazil, occupying large areas of planting, targeting both domestic consumption and the export market. Given its economic importance, the problems caused by the attack of insect pests reduce production and decrease the quality of the grains or seeds [1]. Among the insect groups stands out the velvetbean caterpillar: Anticarsia gemmatalis (Hübner 1818), Lepidoptera: Noctuidae; the brown stink bug: Euschistus heros (Fabricius 1798), Hemiptera: Pentatomidae; the small green stink bug: Piezodorus guildinii (Westwood 1837), Hemiptera: Pentatomidae; and the green stink bug: Nezara viridula (Linneus 1758), Hemiptera: Pentatomidae.

The use of microorganisms has assumed a prominent position among the options that seek to control insect pests without the use of chemicals and with high specific toxicity applied in agroecosystems. The Gram-positive bacterium Bacillus thuringiensis (Berliner 1909), Bt, stands out representing approximately $95 \%$ of microorganisms used in biological control of agricultural pests in different cultures [2]. Besides the economic aspect and the safety to human health [3], this bacterium is the most promising for the production of biopesticides and plant resistant to insects, associated with environmental preservation [4].

Considering the application of $B t$ in the biological control of insects, Hansen and Salamitou [5] reported that the application of this entomopathogen is estimated at 13,000 tons of commercial formulated in the world, mainly applied against 2 Lepidoptera. Currently the largest single market for European biopesticides is Spain, followed by Italy and France. Despite that the overall market growth of biopesticides does not meet the expectations of the 1990s, the potential remains high and there are opportunities that could increase the total market in 2020 [6].

The efficiency of the use of this entomapathogen is characterized by the production, during the sporulation, of crystalline protein inclusions which are toxic to various insect groups. These proteins are produced in the form of protoxins 
and transformed into toxic peptides by a number of events which occur in the midgut after ingestion of $B t$, killing the susceptible insect [7].

$B$. thuringiensis can also serve as a source of toxic genes that can be expressed in plants and thus confer toxic property against different species of insect pests. Genetically modified plants (GMPs) that express the Bt genes, such as rice, corn, potato, cotton, and soybean are associated with the control of pests, especially Lepidoptera. The resistant cultivars result in increased productivity, greater economic value, reduction in the use of chemical pesticides, and benefits in the selectivity of the target pest $[4,8]$. Moreover, $B t$ plants favor the exposure of target insects throughout infestation period, including pests in their most vulnerable stages of development. In another instance, the specificity of toxins of this bacterium is effective for only a limited number of species and the development of resistance to modified plants is more specific than other insecticides [9].

The main pest, the velvetbean caterpillar, is a defoliator insect that can cause complete destruction of the plant $[10$, 11]. In some moments in the development of culture, as in phase between flowering and pod production, the attacked plants are able to withstand only $30 \%$ of defoliation caused by this insect, without incurring losses in seed production [12] Chewing insects are susceptible to control with Bt insecticides when applied on the surface of the leaves or when genes are inserted into the plant genome, such as in the case of soybean. Other insect pests, such as the hemipterans, being endophagous, have no larval stage and her nymphs and adults have sucking mouthparts, not favoring the ingestion of the microorganism.

Stink bugs are insects that come to prominence on soybean because the damage caused by these pests has caused a reduction in productivity. In the USA, in 2008, losses reached US\$13 million [13]. The values of the losses caused by these pentatomids in Brazil are still difficult to be calculated, because they do not present dispersion throughout the national territory, being featured only in isolated regions. The emergence of large populations has been causing concern to farmers, as this pest complex is considered critical because it causes major impacts on key crops worldwide [14].

The lack of new technologies for the control of stink bugs is also worrying due to the increase of the indiscriminate use of insecticides for the direct control of these insects. Besides resistance to chemicals, we can also consider that the increased use of transgenic plant varieties resistant to primary pests has caused a decline in the application of chemical pesticides which in turn favors secondary pests such as stink bugs.

An alternative to the control of these sucking pests is the use of resistant cultivars expressing transgenic $B t$ genes, source of toxicity for the control of caterpillars. However little is known about the effect of $B t$ toxins to pentatomids.

\section{Bacillus thuringiensis}

$B t$ is an aerobic or anaerobic facultative and sporulating bacterium. It can remain latent in the environment even in adverse conditions for its development. Bt can be found in

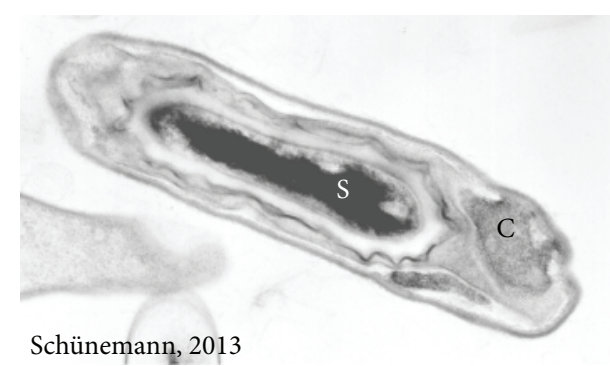

FIGURE 1: Transmission electron microscopy of Bacillus thuringiensis, spore (S), and crystal (C). Magnification 40.000x.

soil, insects and their habitats, stored products, plants, forest, and aquatic environments [15-18].

This bacterium differs from other species belonging to this genus by the presence of a parasporal inclusion body (crystal) of protein origin, formed during sporulation [19] (Figure 1). This crystal is composed of Cry proteins which are encoded by Cry genes [20, 21].

The crystals of bipyramidal, cuboid, rhomboid, oval, spherical, or even no definite shape [22] of a strain of $B t$ toxins may contain up to five different protein whit different molecular weight may vary between 30 and $142 \mathrm{kDa}$ as in the case of strain HD-1 (B. thuringiensis subs. Kurstaki) which produces toxins CrylAa, Cry2Aa, CrylAb, and CrylAc Cry2Aa.

Cyt and Cry proteins that form the crystal, with toxic properties to insects, are soluble in water and belong to the $\delta$-endotoxin class of bacterial proteins. Besides these, $B t$ also produces several other toxins such as $\alpha$-exotoxin, $\beta$-exotoxin, hemolysins, enterotoxins, phospholipases, and chitinase [5].

The $\delta$-endotoxins form two classes of toxins, the first group: $\alpha$-helix toxins or $\alpha$-helical (group of proteins that includes the Cry proteins containing three domains) to which the $\alpha$-helix region of the protein forms a pore in the membrane and the second group: the $\beta$-barrel toxins (includes Cyt proteins), these are inserted into the membrane to form a $\beta$-barrel composed of $\beta$ sheet hairpins from each monomer [23].

According to Monnerat and Bravo [24], the amino acid sequences, when aligned, allow the analysis of similarities between the Cry protein classes, revealing the presence of five blocks of conserved sequences located in the internal regions of the protein and in the contact region between domains. In some of these proteins, the blocks vary their position along the amino acid sequence, whereas others may be completely absent [19].

The relevance of Cry proteins is due to their toxic properties produced after ingestion by insects of different orders [25] and tie order of the toxicity is: Lepidoptera, Diptera, Coleoptera, Hymenoptera, Hemiptera, Isoptera, Orthoptera, Siphonoptera, and Thisanoptera. In the database of Bt ([26]: http://www.lifesci.sussex.ac.uk/home/Neil_Crickmore/Bt), 633 families and subfamilies of Cry proteins with toxic activity including mites, protozoa, and nematodes are described [20, 27-29]. 
TABLE 1: Bacillus thuringiensis genes with toxic activity against Anticarsia gemmatalis in South America.

\begin{tabular}{|c|c|c|c|}
\hline Gene & $\mathrm{kDa}$ & $\mathrm{CL}_{50}$ & Author/local \\
\hline crylAc, crylD & 130 & $1.69 \mathrm{ng} / \mathrm{cm}^{2}$ & \multirow{2}{*}{$\begin{array}{l}\text { Brandtet al. [35] } \\
\text { (Brazil) }\end{array}$} \\
\hline cry $1 A a$, cry $1 A b$, cry $1 A c$, cry $1 C$, cry $1 D$ & 130 & $0.49 \mathrm{ng} / \mathrm{cm}^{2}$ & \\
\hline crylAa, cry1Ac, crylle cry $2 A b$ & & $1.146 \cdot 10^{-6}$ & \multirow{4}{*}{$\begin{array}{l}\text { Silva et al. [32] } \\
\quad \text { (Brazil) }\end{array}$} \\
\hline cry $1 A a$, cry $1 A c$, crylle cry $2 A b$ & & $1.614 \cdot 10^{-6}$ & \\
\hline cry $1 D$, cry $2 A d$ & 130 e 65 & $4.624 \cdot 10^{-7}$ & \\
\hline $\operatorname{cr} y 1 A a, \operatorname{cr} y 1 A b, \operatorname{cr} y 1 A c$, cry $2 A$ & & $1.873 \cdot 10^{-6}$ & \\
\hline $\operatorname{cry} 1 A a, \operatorname{cry} 1 A b, \operatorname{cry} 1 A c$, cry 2 e cry $1 B$ & 130 e 65 & $15.16 \mathrm{ng} / \mathrm{cm}^{2}$ & \multirow{3}{*}{$\begin{array}{l}\text { Praça et al. [36] } \\
\quad \text { (Brazil) }\end{array}$} \\
\hline cry $1 A a$, cry $1 A b$, cry $1 A c$, cry 2 e cry $1 B$ & 130 e 65 & $17.22 \mathrm{ng} / \mathrm{cm}^{2}$ & \\
\hline $\operatorname{cr} y 1 A a$, cry $1 A b$, cry $1 A c$, cry 2 e cry $1 B$ & 130 e 65 & $21.49 \mathrm{ng} / \mathrm{cm}^{2}$ & \\
\hline cryl & & 7 ppm & \multirow{3}{*}{$\begin{array}{c}\text { Franco-Rivera et al. [37] } \\
\text { (Argentina) }\end{array}$} \\
\hline cryl & & $6.7 \mathrm{ppm}$ & \\
\hline cryl, vip $3 A$ & & $8 \mathrm{ppm}$ & \\
\hline $\operatorname{cry} 1 A a$, cry $1 A b$, cry $1 A c$ & 70 to 140 & - & $\begin{array}{c}\text { Berónand Salerno [38] } \\
\text { (Argentina) }\end{array}$ \\
\hline cry $1 A b$, cry 2 & 130 e 65 & $5.1 \mathrm{ng} / \mathrm{cm}^{2}$ & \multirow{4}{*}{$\begin{array}{l}\text { Monnerat et al. [39] } \\
\text { (Brazil) }\end{array}$} \\
\hline cry $1 A a$, cry $1 B$, cry 2 & 130 e 65 & $0.21 \mathrm{ng} / \mathrm{cm}^{2}$ & \\
\hline $\operatorname{cr} y 1 A a, \operatorname{cr} y 1 A b, \operatorname{cr} y 1 A c, \operatorname{cr} y 1 B, \operatorname{cr} y 2$ & 130 e 65 & $3.3 \mathrm{ng} / \mathrm{cm}^{2}$ & \\
\hline cry $1 A a$, cry $1 A b$, cry $1 A c$, cry $1 B e$ cry 2 & 130 e 65 & $13.7 \mathrm{ng} / \mathrm{cm}^{2}$ & \\
\hline cry9Bb, cry1I, vip3 & $131.4,50$, e 70 & $0.78 \mu \mathrm{g} / \mathrm{cm}^{2}(M . \operatorname{sexta})$ & $\begin{array}{c}\text { Silva-Werneck and Ellar [40] } \\
\text { (Brazil) }\end{array}$ \\
\hline cry 1 & 130 & 3.47-8.09 $\mu \mathrm{g} /$ larva & $\begin{array}{l}\text { Gobatto et al. [41] } \\
\text { (Brazil) }\end{array}$ \\
\hline $\operatorname{cry} 2 A a$, cry $2 A b$, cry $2 A c e$ cry $9 A$ & 130,90 e 45 & $0.195 \mu \mathrm{g} /$ larva & \multirow{2}{*}{$\begin{array}{l}\text { Fiuza et al. [42] } \\
\quad \text { (Brazil) }\end{array}$} \\
\hline $\operatorname{cry} 9 A$ & 70,58 e 38 & $0.191 \mu \mathrm{g} /$ larva & \\
\hline
\end{tabular}

Genes that express the delta-endotoxins are called "cry genes" due to the crystalline phenotype. These genes are located on plasmids of large molecular weight. Currently, due to their importance, more than 70 classes of Cry genes are described (cryl the cry70). These endotoxins have been classified as Cryl-Cry69 and Cytl-Cyt3 and different subgroups depending on their amino acid sequence (http:// www.lifesci.sussex.ac.uk/home/Neil_Crickmore/Bt/), [26].

Of these, some $B t$ genes such as $c r y 1 A b, c r y 1 A c, c r y 2 A b$, and $c r y 9 C$ are already being commercially used in GMP such as corn, potato, soybean, and cotton in order to protect against lepidopteran pests of these crops, making it an alternative in reducing the application of chemical pesticides since 1996 [30]. The growth scenario of technology adoption could not be different in Brazil, the second in the world in area planted with GMP. In 2011, 160 million hectares were cultivated with Transgenic plants, with a growth of 12 million hectares compared to 2010, ensuring its place in the ranking of countries that use the technology of genetically modified organisms, behind only the United States [31].

The characterization of Cry genes is important for the differentiation of specific toxicity of Cry proteins active against certain orders of insects. For example, cryl group has several subclasses identified, each of which is responsible for a specific form of activity against various species of insects $[4,15,23,24,32]$. It is widely used in Lepidoptera, whose order focuses most of the studies on the mode of application and action. For some insect groups, such as dipterans or coleopterans, toxicity studies showed that the insecticidal activity of $B t$ has little relevance $[33,34]$.

\section{Toxicity}

Considering the ecology of $B t$, studies performed by Aronson and Shai [56] showed that this microorganism may have a symbiotic relationship with plants, which perhaps explains the production of toxins so specific and efficient against insect pests. However, in the natural environment,several studies indicate that isolates without insecticidal activity are more widely distributed (over 90\%) than those with toxic properties [57, 58].

Currently the demand for new $B t$ strains will increase the number of toxins available for pest control and management of their resistance [59]. Several isolates have been tested and characterized against insect pests and disease vectors to be used as basis for production of biopesticides or as donors of genes encoding insecticidal proteins [60].

In Lepidoptera, toxins are consumed through ingestion. $B t$ toxins classified and studied with insecticidal activity in this group are Cryl, Cry2, Cry9, and Cry15. However only the toxins of the Cryl, Cry2, and Cry9 groups were reported with insecticidal activity to A. gemmatalis (Table 1).

Regarding stink bugs, benefits from the development of an efficient system of integrated management of these pests by soybean farmers can only be achieved if there is improved information on these species, qualitatively and quantitatively. 
TABLE 2: Hemipterans susceptible to different Bacillus thuringiensis toxins.

\begin{tabular}{|c|c|c|c|}
\hline Gene & Species/family & $\mathrm{kDa}$ & Author \\
\hline $\begin{array}{l}\operatorname{cry} 2, \operatorname{cry} 3 A, \\
\operatorname{cry} 4\end{array}$ & $\begin{array}{c}\text { Macrosiphum euphorbiae } \\
\text { Aphididae }\end{array}$ & & Walters and English [43 \\
\hline $\operatorname{cry} 1 A c$ & Lygus hesperus & 65 & Brandt et al. [35] \\
\hline $\operatorname{cry} 2 A b$ & Miridae & 71 & \\
\hline $\operatorname{cry} 5 \mathrm{Ac}$ & $\begin{array}{l}\text { Diprion pini } \\
\text { Diprionidae }\end{array}$ & 58 to 155 & Porcar et al. [44] \\
\hline $\operatorname{cry} 5 \mathrm{Ba}$ & $\begin{array}{c}\text { Pristiphora abietina } \\
\text { Tenthredinidae }\end{array}$ & 58 to 155 & Porcar et al. [44] \\
\hline $\operatorname{cry} 3 A$ & Acyrthosiphon pisum & - & Porcar et al. [45] \\
\hline $\operatorname{cry} 4 A a$ & Aphidoidea & & \\
\hline \multicolumn{4}{|l|}{ cry11Aa } \\
\hline \multicolumn{4}{|l|}{ crylAc } \\
\hline \multirow[t]{3}{*}{$\operatorname{cry} 3 \mathrm{Aa}$} & & $\begin{array}{c}60 \\
25 \text { and } 37\end{array}$ & Li et al. [46] \\
\hline & Podisus nigrispinus & & da Cunha et al. [47] \\
\hline & Pentatomidae & & \\
\hline
\end{tabular}

Agricultural pests of the order Hemiptera, with mouthparts that penetrate and suck, at first, are not able to ingest the insecticide Bt Cry toxins expressed in GMP. Experiments have shown that only biting insects, mites, and thrips [61] are able to ingest the CrylAc protein from $B t$ plants, excluding the sucking pests $[62,63]$.

Monitoring nontarget insects of $B t$ cotton plants expressing CrylAc, Torres and Ruberson [61] suggested that feeding by herbivorous predators of insects susceptible to $B t$ toxin does not imply the development of Podisus maculiventris (Hemiptera: Pentatomidae). It suggests that the cultivation of $B t$ cotton provides an opportunity for the conservation of these predators in these ecosystems, which does not necessarily occur if other Cry proteins are used.

In studies, it has been proven that there is a certain susceptibility by some insects of the order Hemiptera to $B t$ toxins (Table 2). Many studies have investigated the potential effect of Cry toxins on nontarget arthropods in $B t$ plants [35, 64-67].

In some cultures, the population of secondary arthropods, which are not the target of $B t$ application, may be influenced by the implementation of these insecticidal properties [65]. In other agroecosystems, pentatomids of the genus Podisus are predators often used as biological control agents of defoliating caterpillars within the integrated pest management in agriculture and forestry systems already using $B t$ toxins. Of these, we highlight $P$. maculiventris (Say) (Hemiptera: Pentatomidae), which is probably the most important species in Europe and the United States and $P$. nigrispinus (Dallas) (Hemiptera: Pentatomidae) as the main predator species in plantations in Central and South America [68]. Therefore, the improvement and the detailed study of the specificity of $B t$ application become important in the management and preservation of the local ecosystem.

Brandt et al. [35] evaluated the proteolytic processing of the CrylAc and Cry2Ab toxins after their ingestion by
Lygus hesperus Knight (Hemiptera: Miridae) and found the presence of proteolytic processing of toxins into the insect's digestive system. Porcar et al. [44], suggested a Bt strain with insecticidal activity against the three species of this order that are pests of conifers. Walters and English [43] and Porcar et al. [45] suggested toxic activity of isolates containing cry2, cry $3 A$, cry $4 A a$, and cry11Aa genes against the potato aphid, Macrosiphum euphorbiae (Thomas) (Homoptera: Aphididae), and high toxicity to the pea aphid, Acyrthosiphon pisum (Harris) (Hemiptera: Aphididae), showing 100\% mortality after feeding cith $500 \mathrm{~g} / \mathrm{mL}$ or Cry 4 or Cryl1 proteins. In recent histochemistry studies with aphids, Li et al. [46] found that CrylAc toxins were hydrolyzed in the membrane of the stomach by cysteine proteases (CP), whereas Cry3Aa toxins were incompletely processed and partially degraded.

The association of Cry toxins with specific tissues studied by Brandt et al. [35] demonstrated that following ingestion of the CrylAc toxin activated with trypsin, the hemipteran $L$. hesperus has no receptor to this protein, but a wide link to in the microvilli of intestinal cells throughout the intestine for the Cry2Ab toxin.

The low susceptibility of these insects to $B t$ toxins may be related to similarities between the glycoproteins from insect midgut microvilli and not as a result of direct selection for toxicity, as shown by Li et al. [46]. In vivo assays showed that the toxins used showed low activity against the aphids, which may be related to the way the experiments were performed. Once nonsolubilized $B t$ crystals have been used in feeding assays, which present a disadvantage since the solubilization of the toxin does not occur due to the acidic $\mathrm{pH}$ in the stomach of these insects [69]. The proteolytic activation of the $B t$ toxin ingested in the gut of insects is essential to present toxicity. The differences between the proteolytic enzymes (abundance, type, and its correlation) and the $\mathrm{pH}$ of the midgut of hemipterans, as well as other pests, are factors that contribute to toxicity [46]. 


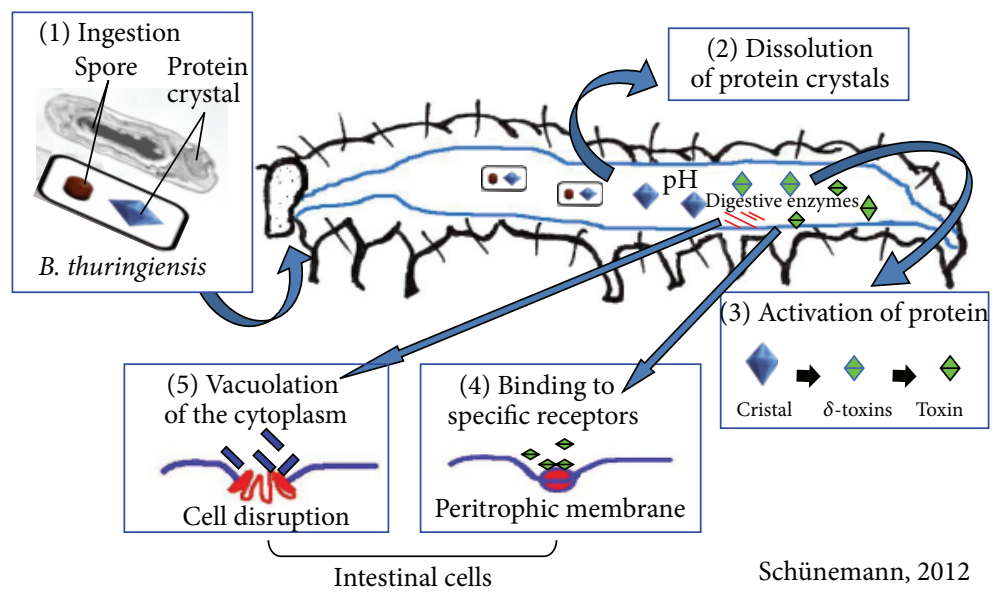

FIGURE 2: Mode of action of Bacillus thuringiensis in Lepidoptera: ingestion of bacteria (1); solubilization of the crystals (2); activation protein (3); binding of proteins to the receptors (4); membrane pore formation and cell lise (5).

The intramolecular proteolytic cleavage is also important for toxicity against insects which have gut with acid or neutral $\mathrm{pH}$, as this favors the creation of $B t$ plants that express Cry toxins instead of protoxins. The intramolecular proteolytic cleavage increases the solubility of the toxin in the gut, thereby facilitating its binding. These polypeptides can also associate with others and maintain the insecticidal activity [14]. This phase has been extensively studied using Cryl toxins that involves removal of 27-29 N-terminal amino acids 500-600 and C-terminal amino acids. Hemipterans present acid gut and the proteolytic activities of the membrane are associated with cathepsin of the types $\mathrm{G}$ and B $[69,70]$.

More detailed studies carried out by da Cunha et al. [47], with the same insect, showed that the CrylAc toxin expressed in this plant generated humoral and cellular changes as a sign of response to a xenobiotic. The toxin ingested by a lepidopteran (third trophic level) induced changes in the distribution of glycogen, lipids, and calcium due to the disorganization of the perimicrovilllar matrix of the gut.

\section{Histology and Mode of Action}

Histological studies, using the insects gut, have been the focus of researches to control agricultural pests. This is due the fact that changes in the gut can not only affect their development, but also cause major physiological events, such as changes in nutrient absorption, degenerative transformation, appetite loss and abandonment of food, gut paralysis, physiological disorders, and total paralysis. These are the most common symptoms observed from the moment the susceptible insects ingest the $B t$ spores and crystals, leading to insect death, when larvae show a blackened color, a characteristic symptom of infections caused by this microorganism [24].

In lepidopterans, the chewing mouthparts promote the ingestion of $B t$ toxins both in a product form and in the form of a toxin-containing GMP. Their digestive tract is divided into three regions: preintestine (front), midgut, and hindgut and is one of the most important areas of contact between the insect and the environment. This has been the subject of research aiming to develop alternative control methods [71].

In caterpillars, the midgut epithelium, pseudostratified columnar, consists of four types of cells, which are involved in the processes of absorption and secretion of enzymes, which are columnar and caliciform cells with ionic homeostasis function, endocrine cells with endocrine function, and regenerative cells involved in the renewal of the epithelium [71]. All of them are coated by a peritrophic membrane, which serves to protect the epithelium from mechanical damage and also as a barrier against harmful chemicals and toxins.

According to Levy et al. [71], the columnar cells are in larger quantities, tall, and present long and numerous microvilli on the apical portion. The basal portion, invaginations form the basal labyrinth. The caliciform cells have a large central cavity delimitated by cytoplasmic projections filled with mitochondria. The regenerative cells present an electron-dense cytoplasm and few organelles. The endocrine cells are characterized by the presence of electron-dense secretory granules concentrated in the cytoplasm of the basal cell.

Several histopathological and ultrastructural studies have investigated the interaction between $B t$ toxins in the midgut of larvae of these insects [72-77]. In Figure 2, the series of events that occur after ingestion of $B t$ in Lepidoptera are shown.

After ingestion, the crystals are solubilized in the alkaline ( $\mathrm{pH} 9$ to 12) midgut environment [78]. The proteins specific for Lepidoptera are soluble at $\mathrm{pH}$ above 9.5 [79]. The $\mathrm{pH}$ of the midgut of insects has great influence on the specific activity of Cry toxins. Some toxins are activated under alkaline conditions (CryII1A) and others are activated under conditions of neutral to acid pH (Crylb) [23]. Cleavage of Cry toxins is a crucial step in the activation of the toxin and also in its specificity in different insects.

When toxins are solubilized, protoxins are released through the action of proteases resulting in active proteins of $60-70 \mathrm{kDa}$ [80]. Their toxic fragments were described as 
connected to the $\mathrm{N}$-terminal region of the polypeptide chain, which is later removed [81].

The protoxins are activated by digestive enzymes in the midgut and bind to specific receptors in the microvilli of the apical membranes of the columnar cells of the lepidopterans gut [19]. The binding of Cry toxins to the apical microvillus of the membrane vesicles of the insect determines the specificity of the Cry toxins [23].

Different proteins have been identified as receptors for $B t$ in Lepidoptera, and we can highlight with Lepidptera, including aminopeptidases [82], "cadherin-like protein" [83], and alkaline phosphatase [84].

The binding method may be described as a biphasic step consisting of reversible and irreversible stage $[85,86]$. The interaction between the toxin and its binding site is a basic requirement for the toxicity [20]. The degree of toxicity is determined when the insertion in the cell membrane is considered irreversible binding [24].

The molecules for binding of Cry proteins are a cadherin type protein (CADR), an aminopeptidase anchored to a glicosilfosfatidil-N-inositol (GPI), an alkaline phosphatase anchored to a glicosilfosfatidil-inositol (GPI), and a $270 \mathrm{kDa}$ glycoconjugate [23, 87]. Other experiments have shown that glycolipids may also be involved as receptor molecules in some insects and nematodes [87]. Studies conducted by Zhang et al. [88] suggested that the toxicity may be related to G-protein-mediated apoptosis upon binding to the receptor.

The Cry toxins cross the peritrophic membrane by binding to specific receptors on the apical membranes of intestinal cells causing opening or pore formation followed by vacuolation of the cytoplasm by osmotic imbalance between the intracellular and extracellular environments and cell disruption. This destroys the microvilli, causing the insect to stop feeding, leading to its death $[7,23,76,89,90]$.

A second model to describe the mode of action of Cry toxins has been proposed by Zhang et al. [88] and refers to signal transduction. Although being only studied in insect cells, it does not differ from the first model to the stage of binding the protein formed by cleavage of the protoxin in intestinal microvilli.

Regarding stink bugs, these present needle-like sucking mouthparts that are formed by two mandibular and two maxillary stylets and a narrow channel which injects saliva in the salivary plant tissue. The digestion of these insects is extra-oral, secreting saliva in the food, which digests sap proteins using proteases present in saliva [91]. After sucking predigested nutrients, they are completely digested by proteases in the gut for absorption of nutrients.

The midgut of Hemiptera varies in its morphology and functional activity due to dietary habits of these insects. It is divided into an anterior dilated region, a median tubular region, and posterior dilated one [92]. The anterior region is responsible for electrolyte balance and involves the transport of ions and water and digestion of carbohydrates and is an important location for the storage of lipids. The process of digestion enzyme secretion is generally observed in the middle and posterior regions. Histologically, the pentatomids midgut has a simple epithelial layer and consists of digestive cells and regenerative distributed of all throughout the midgut. The hemipterans have no peritrophic membrane, therefore they are unprotected by a chitin and protein membrane that prevents the action of pathogens and excretion of digestive enzymes [93].

\section{Application of $B t$ Technologies}

5.1. Bt Products. Despite the importance and viability of microbial agents for pest control, only $2 \%$ of the insecticides used worldwide are based on the application of biopesticides, in which $B t$ represents approximately $95 \%$ of microorganisms used [94]. For over 50 years, $B t$ has been used in formulations for the biological control of many agricultural pests and vectors of human diseases and based on more than $90 \%$ of commercially available microorganism products $[95,96]$.

Since the first product has been launched in France in 1938, over 100 formulations were placed in the world market, with the American continent being responsible for $50 \%$ of this market [97]. From this fraction, the United States and Canada account for $90 \%$ and the countries of Latin America ranking with only $8-10 \%$ of consumption concentrated, mainly in Cuba and Mexico, to control pests in cotton, banana, potato, citrus, vegetables, tobacco, corn, and pasture. In Brazil $B t$-based products are used in approximately 150,000 acres [90] for the control of about 30 pests with agricultural importance.

There are different commercial Bt products developed for control agricultural insect pests and also against mosquito species. Most of the spore-crystal formulations are obtained from different strains. These include $B$. thuringiensis var. kurstaki (Btk)-isolate HD1 (contains CrylAa, CrylAb, CrylAc, and Cry2Aa proteins); B. thuringiensis var. kurstaki (Btk)-isolate HD73 (contains CrylAc); B. thuringiensis var. aizawai-isolate HD137 (contains CrylAa, CrylB, CrylCa, and CrylDa); B. thuringiensis var. San Diego and B. thuringiensis var. tenebrionis, (which contains Cry3Aa); B. thuringiensis var. israelensis (containing Cry4A, Cry4B, CryllA, and Cyt1Aa) toxins.

5.2. Bt Plants. A selection of different soybean cultivars with resistance against lepidopterans and other insect classes. This occurs through genetic improvement of plants which express chemical characteristics that involve the production of toxins such as isoflavonoids, that act as repellents, feeding and oviposition suppressors, and digestibility reducers of these insects, is also a way to reduce the damage caused by these insects [98]. The use of these plants with other techniques of integrated pest management (IPM) can keep the pest population levels below the levels of economic damages [99].

The insecticidal effect of GMPs on natural enemies is a controversial topic. Even after rigorous risk assessment, planting these cultivars has aroused concern over environmental impacts such as gene escape and effects on biodiversity. Considering soybeans, the risk of horizontal gene transfer is remote because of the lack of compatible wild species. The gene escape to the conventional crops can occur but can be avoided by isolation of the cultures $[100,101]$.

Plants with insecticidal activity, since they are rapidly degradable, reduce environmental impact, in addition to 
TABLE 3: Papers published with the transformation of Bt Soybean.

\begin{tabular}{|c|c|c|c|}
\hline Gene & Insects & Effects & References \\
\hline crylAb native & Anticarsia gemmatalis & $\begin{array}{c}\text { Prevention of larvae feeding } \\
\text { and growth }\end{array}$ & Parrott et al. [48] \\
\hline $\begin{array}{l}\text { crylAc }(t i c 107) \\
\text { synthetic } \\
\text { MON87701 event } \\
\text { (Protein TIC107) }\end{array}$ & $\begin{array}{l}\text { Anticarsia gemmatalis } \\
\text { Pseudoplusia includens }\end{array}$ & Tolerant to attack & Fischhoff and Perlak [49] \\
\hline crylAc synthetic & Anticarsia gemmatalis & $\begin{array}{l}100 \% \text { mortality to } A . \\
\text { gemmatalis }\end{array}$ & Stewart Jr et al. [50] \\
\hline crylAc synthetic & $\begin{array}{c}\text { Pseudoplusia includens } \\
\text { Helicoverpa zea }\end{array}$ & $\begin{array}{c}\text { Decrease of feeding and } \\
\text { survival }\end{array}$ & Walker et al. [51] \\
\hline crylA synthetic & $\begin{array}{c}\text { Anticarsia gemmatalis } \\
\text { Pseudoplusia includens, } \\
\text { Epinotia aporema } \\
\text { Rachiplusia nu } \\
\text { Spilosoma virginica }\end{array}$ & $\begin{array}{c}\text { Elimination of infestation in } \\
\text { greenhouse }\end{array}$ & MacRae et al. [52] \\
\hline crylA synthetic & $\begin{array}{c}\text { Pseudoplusia includes } \\
\text { Helicoverpa zea } \\
\text { Anticarsia gemmatalis }\end{array}$ & High level of resistance & Miklos et al. [53] \\
\hline crylAc synthetic & Anticarsia gemmatalis & Highly toxic & Homrich et al. [54] \\
\hline $\operatorname{cry} 1 A c(t i c 107)$ & $\begin{array}{c}\text { Anticarsia gemmatalis } \\
\text { Pseudoplusia includens } \\
\text { Hypena scabra }\end{array}$ & $\begin{array}{c}\text { Elimination of infestation in } \\
\text { greenhouse }\end{array}$ & McPherson and MacRae [55] \\
\hline
\end{tabular}

maintaining the beneficial fauna [102]. Their resistance may contribute to the reduction of the insect population below the economic injury level, do not cause imbalances in agroecosystems, and have a cumulative and persistent effect. They do not promote increases in production costs and are compatible with other control tactics [103].

Transgenic soybean is the main culture that currently occupies the crops of GMPs in the world, occupying $47 \%$ of the 160 million hectares of GM crops currently grown in the area in 2011. The soybean transformation was first reported in 1988 [104, 105]. To date, the transformation is not yet considered routine due to the complexity of combining techniques for its transformation and regeneration [54]. Transgenic soybean is an important tool for achieving economic growth of this crop in Brazil; however, it is essential to know how to use this technology and associate it with other tools.

$B t$ soybean is the second largest group of GMPs within this culture [106]. The cultivars are characterized by expressing Cry toxins with insecticidal properties to groups of insect pests of this crop. The toxins are expressed by cloned Cry genes from $B t$ and hence comes the name of the cultivar: $B t$ soybean. In Table 3 , there are the papers published with the transformation of $B t$ soybean.

There is a great concern in making $B t$ available in large areas, as it may lead to selection of resistant phenotypes to this toxin. Susceptibility studies of toxic proteins to the major target pests have become important to obtain susceptibility levels and determine the diagnostic doses for future monitoring of possible changes in susceptibility.

In Brazil, research is limited to selecting isolates through bioassays and the description of its Cry genes. In the case of soybean, the $B t$ soybean roundup ready $2 y i e l d$ (BtRR2Y) that expresses the CrylAc protein is produced on a commercial scale.

\section{Final Considerations and Future Prospects}

There are increasingly records of $B t$ isolates showing toxic activity to some insect pests. But in the market, there are few toxins of this microorganism used in formulated products and GMPs and may quickly cause the emergence of resistant populations. This fact occurred in different populations of Lepidoptera exposed to Cry toxins [107].

It is clear that cultures that express $B t$ toxins have had a very important beneficial impact on global agriculture due to the reduction in the number of pests and hence the total application of chemical insecticides used for its control, as well as the final production.

The large-scale cultivation of genetically modified crops over several years may increase the selective pressure on the pest species, which may result in the development of resistance [108]. Resistance to insect control practices is a threat to development, implementation, and maintenance of IPM practices. The emergence of resistance is often related to the reduction of pest populations by the increased mortality or reduced fecundity in insects. Thus, when there are differences in survival or fecundity between the specimens that form the population of a pest species after use of Cry proteins, the selection of resistant insects to protection techniques recently applied may occur.

Therefore, when there is significant variability in insect population with any physiological or behavioral characteristics that contrast the protection to Cry proteins insecticides, 
B. thuringiensis $\mathrm{X}$ soybean pest

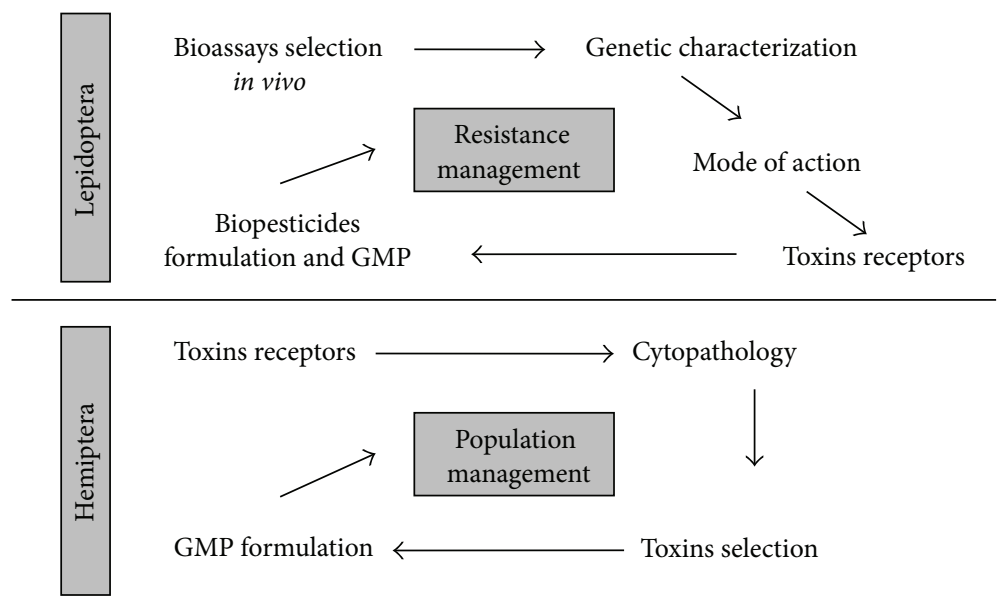

FIGURE 3: Comparative analysis of studies of the evolution of application of Bacillus thuringiensis to control caterpillars and stink bugs in agroecosystems.

it is formed an inevitable selection of adapted insect pests. Thus, it essential to observe proper practices in the integrated management (IPM) of this pest, avoiding a continuous selection of resistant specimens, reducing the frequency of resistance that may compromise the protection to crops by pests.

Due to the large potential that pest populations have to develop resistance, some strategies have already been implemented in other cultures. As an example, using vegetative insecticidal proteins (VIPs) and using genes from plants or animals which encode immunosuppressive proteins [109].

In the cultivation of $B t$ soybean, the most recommended technique is the use of refuge areas. This consists of partially planting non- $B t$ plants in the area of soybean containing $B t$ proteins. The importance is to keep population of the target pest without exposure to $B t$ crops and thus sensitive to the proteins. This way, pest individuals that develop in the refuge can mate with any resistant individuals that may have survived in the culture. This would convey susceptibility to $B t$ for future generations of the pest, generating resistant and susceptible individuals within the population, preserving the $B t$ technology.

Thus, assessing the mode of action of Cry toxins is a complex process that involves interaction with the receptor molecules that lead to different mechanisms of membrane insertion and lysis of intestinal cells. However the characterization of the mode of action of Cry toxins in other susceptible organisms may be important for understanding the mode of action of this protein family in different insects, which often do not show insecticidal activity with in vivo toxicity tests. The analysis of interaction between insects and bacteria is essential for effective management of the target species, and steps for evaluation may not be the same for both (Figure 3). Advanced studies provided detailed techniques in each step of interaction between insect and pathogen, which can reveal new ways of using $B t$ toxins.

However, there is no information about the digestive physiology of hemipterans associated with $B t$ toxins, and no literature regarding the mechanism of resistance or susceptibility of these insects to Cry toxins is available. Thus, in Brazil where these species have an agricultural importance, it is necessary to evaluate the in vitro action of Cry proteins in the gut of these insects, testing the hypothesis of degradation or activation of Cry toxins in the gut of these pentatomids.

This knowledge may be through the identification of novel molecules and the development of bioinsecticides. In this context, it is of great importance the discovery of bacterial strains with increased activity, adapted to environmental conditions and with high specificity. Thus, the mapping of new Cry proteins to nonsusceptible insects and specificities of the receptors may be critical for the development of new products for the control of these insects.

Studies on the identification of receptor molecules and binding sites, especially in Hemiptera and Lepidoptera, are important for the development of strategies to control insect resistance. In addition, knowledge of the target molecules for insecticides for agricultural pests is also essential to use in GMPs in order to control the different susceptible targets to the toxins used.

\section{Conflict of Interests}

The authors declare that there is no conflict of interests regarding the publication of this paper.

\section{References}

[1] C. Rohde and M. Z. Schuster, "Associação entre inseticida biológico (Bacillus thuringiensis) com subdosagens de regulador de crescimento para o controle da Anticarsia gemmatalis (Lepidoptera: Noctuidae) na cultura da soja," Revista Brasileira de Tecnologia Aplicada nas Ciências Agrárias, vol. 5, pp. 131-146, 2012.

[2] B. Lambert, H. Höfte, K. Annys, S. Jansens, P. Soetaert, and M. Peferoen, "Novel Bacillus thuringiensis insecticidal crystal protein with a silent activity against coleopteran larvae," Applied 
and Environmental Microbiology, vol. 58, no. 8, pp. 2536-2542, 1992.

[3] J. P. Siegel, "The mammalian safety of Bacillus thuringiensisbased insecticides," Journal of Invertebrate Pathology, vol. 77, no. 1, pp. 13-21, 2001.

[4] K. van Frankenhuyzen, "Insecticidal activity of Bacillus thuringiensis crystal proteins," Journal of Invertebrate Pathology, vol. 101, no. 1, pp. 1-16, 2009.

[5] B. M. Hansen and S. Salamitou, "Virulence of Bacillus thuringiensis," in Entomopathogenic Bacteria: From Laboratory to Field Application, J. F. Charles, A. Delecluse, and C. NielsenLe Roux, Eds., pp. 41-44, Kluwer Academic, Dodrecht, The Netherlands, 2000.

[6] S. Gupta and A. K. Dikshit, "Biopesticides: an ecofriendly approach for pest control," Journal of Biopesticides, vol. 3, no. 1, pp. 186-188, 2010.

[7] L. M. Fiuza, "Receptores de Bacillus turingiensis em insetos," Biotecnologia Ciência e Desenvolvimento, vol. 32, pp. 84-89, 2004.

[8] A. M. Shelton, J. Zhao, and R. T. Roush, "Economic, ecological, food safety, and social consequences of the deployment of Bt transgenic plants," Annual Review of Entomology, vol. 47, pp. 845-881, 2002.

[9] M. Qaim, "The economics of genetically modified crops," Annual Review Resoursch Economic, vol. 1, pp. 665-693, 2009.

[10] G. L. M. Martins, L. C. Toscano, G. V. Tomquelski, and W. I. Maruyama, "Inseticidas no controle de Anticarsia gemmatalis (Lepidoptera: Noctuidae) e impacto sobre aranhas predadoras em soja," Revista Brasileira de Ciências Agrárias, vol. 4, pp. 128$132,2009$.

[11] A. L. Lourenção, P. C. Reco, N. R. Braga, G. E. Valle, and J. B. Pinheiro, "Produtividade de genótipos de soja sob infestação da lagarta-da-soja e de percevejos," Neotropical Entomology, vol. 39, pp. 275-281, 2010.

[12] D. Gallo, O. Nakano, S. S. Neto et al., Entomologia Agrícola, FEALQ, Piracicaba, Brazil, 2002.

[13] F. P. F. Reay-Jones, "Spatial and temporal patterns of stink bugs (Hemiptera: Pentatomidae) in wheat," Environmental Entomology, vol. 39, no. 3, pp. 944-955, 2010.

[14] N. P. Chougule and B. C. Bonning, "Toxins for transgenic resistance to hemipteran pests," Toxins, vol. 4, no. 6, pp. 405429, 2012.

[15] L. M. Fiuza, "Bacillus thuringiensis: características e potencial no manejo de insetos," Acta Biologica Leopoldensia, vol. 23, pp. 141-156, 2001.

[16] C. S. Hernández, R. Andrew, Y. Bel, and J. Ferré, "Isolation and toxicity of Bacillus thuringiensis from potato-growing areas in Bolivia," Journal of Invertebrate Pathology, vol. 88, no. 1, pp. 816, 2005.

[17] M. F. Bizzarri and A. H. Bishop, "The ecology of Bacillus thuringiensis on the phylloplane: colonization from soil, plasmid transfer, and interaction with larvae of Pieris brassicae," Microbial Ecology, vol. 56, no. 1, pp. 133-139, 2008.

[18] F. Al-Momani and M. Obeidat, "Ecology, toxicity, and hydrolytic activities of Bacillus thuringiensis in forests," Turkish Journal of Agriculture and Forestry, vol. 36, pp. 1104-1133, 2012.

[19] H. Höfte and H. R. Whiteley, "Insecticidal crystal proteins of Bacillus thuringiensis," Microbiological Reviews, vol. 53, no. 2, pp. 242-255, 1989.

[20] E. Schnepf, N. Crickmore, J. van Rie et al., "Bacillus thuringiensis and its pesticidal crystal proteins," Microbiology and Molecular Biology Reviews, vol. 62, no. 3, pp. 775-806, 1998.
[21] N. Crickmore, D. R. Zeigler, J. Feitelson et al., "Revision of the nomenclature for the Bacillus thuringiensis pesticidal crystal proteins," Microbiology and Molecular Biology Reviews, vol. 62, no. 3, pp. 807-813, 1998.

[22] M. E. M. Habib and C. F. S. Andrade, "Bactérias entomopatogênicas," in Controle microbiano de insetos, S. B. Alves, Ed., pp. 383-446, FEALQ, Piracicaba, Brazil, 1998.

[23] A. Bravo, S. S. Gill, and M. Soberón, "Mode of action of Bacillus thuringiensis Cry and Cyt toxins and their potential for insect control," Toxicon, vol. 49, no. 4, pp. 423-435, 2007.

[24] R. G. Monnerat and A. Bravo, "Proteínas bioinseticidas produzidas pela bactéria Bacillus thuringiensis: Modo de ação e resistência," in Controle Biológico, I. S. Melo and J. L. Azevedo, Eds., pp. 163-200, Embrapa-CNPMA, Jaguariúna, Brazil, 2000.

[25] N. Crickmore, "Using worms to better understand how Bacillus thuringiensis kills insects," Trends in Microbiology, vol. 13, no. 8, pp. 347-350, 2005.

[26] N. Crickmore, Bacillus thuringiensis Nomenclature, 2012, http://www.lifesci.sussex.ac.uk/home/Neil_Crickmore/Bt/.

[27] M. Porcar and V. Juárez-Pérez, "PCR-based identification of Bacillus thuringiensis pesticidal crystal genes," FEMS Microbiology Reviews, vol. 26, no. 5, pp. 419-432, 2003.

[28] B. Tian, J. Yang, and K. Zhang, "Bacteria used in the biological control of plant-parasitic nematodes: populations, mechanisms of action, and future prospects," FEMS Microbiology Ecology, vol. 61, no. 2, pp. 197-213, 2007.

[29] G. S. Jouzani, A. Seifinejad, A. Saeedizadeh et al., "Molecular detection of nematicidal crystalliferous Bacillus thuringiensis strains of Iran and evaluation of their toxicity on free-living and plant-parasitic nematodes," Canadian Journal of Microbiology, vol. 54, no. 10, pp. 812-822, 2008.

[30] G. A. Kleter, R. Bhula, K. Bodnaruk et al., "Altered pesticide use on transgenic crops and the associated general impact from an environmental perspective," Pest Management Science, vol. 63, no. 11, pp. 1107-1115, 2007.

[31] C. James, "Global status of commercialized Biotech/GM 25 crops: 2011," ISAAA Brief 43-2011: Status Global das Variedades Transgênicas/Biotecnológicas Comerciais, 2011, http://www.isaaa.org/resources/publications/briefs/43/.

[32] F. B. Silva, J. A. N. Batista, B. M. Marra et al., "Pro domain peptide of HGCP-Iv cysteine proteinase inhibits nematode cysteine proteinases," Genetics and Molecular Research, vol. 3, no. 3, pp. 342-355, 2004.

[33] S. Mohammedi, S. B. Subramanian, S. Yan, R. D. Tyagi, and J. R. Valéro, "Molecular screening of Bacillus thuringiensis strains from wastewater sludge for biopesticide production," Process Biochemistry, vol. 41, no. 4, pp. 829-835, 2006.

[34] G. Armengol, M. C. Escobar, M. E. Maldonado, and S. Orduz, "Diversity of Colombian strains of Bacillus thuringiensis with insecticidal activity against dipteran and lepidopteran insects," Journal of Applied Microbiology, vol. 102, no. 1, pp. 77-88, 2007.

[35] S. L. Brandt, T. A. Coudron, J. Habibi et al., "Interaction of two Bacillus thuringiensis $\delta$-endotoxins with the digestive system of Lygus hesperus," Current Microbiology, vol. 48, no. 1, pp. 1-9, 2004.

[36] L. B. Praça, A. C. Batista, E. S. Martins et al., "Estirpes de Bacillus Thuringiensis efetivas contra insetos das Ordens Lepidoptera, Coleoptera e Diptera," Pesquisa Agropecuaria Brasileira, vol. 39, pp. 11-16, 2004.

[37] A. Franco-Rivera, G. Benintende, J. Cozzi, V. M. BaizabalAguirre, J. J. Valdez-Alarcón, and J. E. López-Meza, "Molecular characterization of Bacillus thuringiensis strains from 
Argentina," Antonie van Leeuwenhoek, vol. 86, no. 1, pp. 87-92, 2004.

[38] C. M. Berón and G. L. Salerno, "Characterization of Bacillus thuringiensis isolates from Argentina that are potentially useful in insect pest control," BioControl, vol. 51, no. 6, pp. 779-794, 2006.

[39] R. G. Monnerat, A. C. Batista, P. T. de Medeiros et al., "Screening of Brazilian Bacillus thuringiensis isolates active against Spodoptera frugiperda, Plutella xylostella and Anticarsia gemmatalis," Biological Control, vol. 41, no. 3, pp. 291-295, 2007.

[40] J. O. Silva-Werneck and D. J. Ellar, "Characterization of a novel Cry9Bb $\delta$-endotoxin from Bacillus thuringiensis," Journal of Invertebrate Pathology, vol. 98, no. 3, pp. 320-328, 2008.

[41] V. Gobatto, S. G. Giani, M. Camassola, A. J. P. Dillon, A. Specht, and N. M. Barros, "Bacillus thuringiensis isolates entomopathogenic for Culex quinquefasciatus (Diptera: Culicidae) and Anticarsia gemmatalis (Lepidoptera: Noctuidae)," Brazilian Journal of Biology, vol. 70, no. 4, pp. 1039-1046, 2010.

[42] L. M. Fiuza, R. Schünemann, L. M. N. Pinto, and M. H. B. Zanettini, "Two new Brazilian isolates of Bacillus thuringiensis toxic to Anticarsia gemmatalis (Lepidoptera: Noctuidae )," Brazilian Journal of Biology, vol. 72, pp. 363-369, 2012.

[43] F. S. Walters and L. H. English, "Toxicity of Bacillus thuringiensis $\delta$-endotoxins toward the potato aphid in an artificial diet bioassay," Entomologia Experimentalis et Applicata, vol. 77, no. 2, pp. 211-216, 1995.

[44] M. Porcar, F. Gómez, A. Gruppe, A. Gómez-Pajuelo, I. Segura, and R. Schröder, "Hymenopteran specificity of Bacillus thuringiensis strain PS86Q3," Biological Control, vol. 45, no. 3, pp. 427-432, 2008.

[45] M. Porcar, A. Grenier, B. Federici, and Y. Rahbé, "Effects of Bacillus thuringiensis $\delta$-endotoxins on the pea aphid (Acyrthosiphon pisum)," Applied and Environmental Microbiology, vol. 75, no. 14, pp. 4897-4900, 2009.

[46] H. Li, N. P. Chougule, and B. C. Bonning, "Interaction of the Bacillus thuringiensis $\delta$ endotoxins CrylAc and Cry3Aa with the gut of the pea aphid, Acyrthosiphon pisum (Harris)," Journal of Invertebrate Pathology, vol. 107, no. 1, pp. 69-78, 2011.

[47] F. M. da Cunha, F. H. Caetano, V. Wanderley-Teixeira, J. B. Torres, A. A. C. Teixeira, and L. C. Alves, "Ultra-structure and histochemistry of digestive cells of Podisus nigrispinus (Hemiptera: Pentatomidae) fed with prey reared on bt-cotton," Micron, vol. 43, no. 2-3, pp. 245-250, 2012.

[48] W. A. Parrott, J. N. All, M. J. Adang, M. A. Bailey, H. R. Boerma, and C. N. Stewart Jr., "Recovery and evaluation of soybean plants transgenic for a Bacillus thuringiensis var. Kurstaki insecticidal gene," In Vitro Cellular \& Developmental Biology, vol. 30, no. 3, pp. 144-149, 1994.

[49] D. A. Fischhoff and F. J. Perlak, "Synthetic plant genes," U.S. Patent \# 5: 500, 365, 1995.

[50] C. N. Stewart Jr., M. J. Adang, J. N. All et al., "Genetic transformation, recovery, and characterization of fertile soybean transgenic for a synthetic Bacillus thuringiensis cryIAc gene," Plant Physiology, vol. 112, no. 1, pp. 121-129, 1996.

[51] D. R. Walker, J. N. All, R. M. McPherson, H. R. Boerma, and W. A. Parrott, "Field evaluation of soybean engineered with a synthetic crylAc transgene for resistance to corn earworm, soybean looper, velvetbean caterpillar (Lepidoptera: Noetuidae), and lesser cornstalk borer (Lepidoptera: Pyralidae)," Journal of Economic Entomology, vol. 93, no. 3, pp. 613-622, 2000.

[52] T. C. Macrae, M. E. Baur, D. J. Boethel et al., "Laboratory and field evaluations of transgenic soybean exhibiting high-dose expression of a synthetic Bacillus thuringiensis crylA gene for control of lepidoptera," Journal of Economic Entomology, vol. 98, no. 2, pp. 577-587, 2005.

[53] J. A. Miklos, M. F. Alibhai, S. A. Bledig et al., "Characterization of soybean exhibiting high expression of a synthetic Bacillus thuringiensis crylA transgene that confers a high degree of resistance to lepidopteran pests," Crop Science, vol. 47, no. 1, pp. 148-157, 2007.

[54] M. S. Homrich, L. M. P. Passaglia, J. F. Pereira et al., "Resistance to Anticarsia gemmatalis Hübner (Lepidoptera, Noctuidae) in transgenic soybean (Glycine max (L.) Merrill Fabales, Fabaceae) cultivar IAS5 expressing a modified CrylAc endotoxin," Genetics and Molecular Biology, vol. 31, no. 2, pp. 522-531, 2008.

[55] R. M. McPherson and T. C. MacRae, "Assessing lepidopteran abundance and crop injury in soybean lines exhibiting a synthetic Bacillus thuringiensis crylA gene," Journal of Entomological Science, vol. 44, no. 2, pp. 120-131, 2009.

[56] A. I. Aronson and Y. Shai, "Why Bacillus thuringiensis insecticidal toxins are so effective: unique features of their mode of action," FEMS Microbiology Letters, vol. 195, no. 1, pp. 1-8, 2001.

[57] K. Yasutake, A. Uemori, K. Kagoshima, and M. Ohba, "Serological identification and insect toxicity of Bacillus thuringiensis isolated from the island Okinoerabu-jima, Japan," Applied Entomology and Zoology, vol. 42, no. 2, pp. 285-290, 2007.

[58] M. Ohba, N. Wasano, and E. Mizuki, "Bacillus thuringiensis soil populations naturally occurring in the Ryukyus, a subtropic region of Japan," Microbiological Research, vol. 155, no. 1, pp. 17$22,2000$.

[59] B. E. Tabashnik, A. J. Gassmann, D. W. Crowder, and Y. Carrière, "Insect resistance to Bt crops: evidence versus theory," Nature Biotechnology, vol. 26, no. 2, pp. 199-202, 2008.

[60] A. Bravo, S. Likitvivatanavong, S. S. Gill, and M. Soberón, "Bacillus thuringiensis: a story of a successful bioinsecticide," Insect Biochemistry and Molecular Biology, vol. 41, no. 7, pp. 423431, 2011.

[61] J. B. Torres and J. R. Ruberson, "Interactions of Bacillus thuringiensis CrylAc toxin in genetically engineered cotton with predatory heteropterans," Transgenic Research, vol. 17, no. 3, pp. 345-354, 2008.

[62] A. Raps, J. Kehr, P. Gugerli, W. J. Moar, F. Bigler, and A. Hilbeck, "Immunological analysis of phloem sap of Bacillus thuringiensis corn and of the nontarget herbivore Rhopalosiphum padi (Homoptera: Aphididae) for the presence of CrylAb," Molecular Ecology, vol. 10, no. 2, pp. 525-533, 2001.

[63] J. B. Torres, J. R. Ruberson, and M. J. Adang, "Expression of Bacillus thuringiensis CrylAc protein in cotton plants, acquisition by pests and predators: a tritrophic analysis," Agricultural and Forest Entomology, vol. 8, no. 3, pp. 191-202, 2006.

[64] H. A. Bell, R. E. Down, E. C. Fitches, J. P. Edwards, and A. M. R. Gatehouse, "Impact of genetically modified potato expressing plant-derived insect resistance genes on the predatory bug Podisus maculiventris (Heteroptera: Pentatomidae)," Biocontrol Science and Technology, vol. 13, no. 8, pp. 729-741, 2003.

[65] J. Romeis, D. Bartsch, F. Bigler et al., "Assessment of risk of insect-resistant transgenic crops to nontarget arthropods," Nature Biotechnology, vol. 26, no. 2, pp. 203-208, 2008.

[66] G. L. Lövei, D. A. Andow, and S. Arpaia, "Transgenic insecticidal crops and natural enemies: a detailed review of laboratory studies," Environmental Entomology, vol. 38, no. 2, pp. 293-306, 2009.

[67] M. García, F. Ortego, P. Castañera, and G. P. Farinós, "Effects of exposure to the toxin CrylAb through Bt maize fed-prey on 
the performance and digestive physiology of the predatory rove beetle Atheta coriaria," Biological Control, vol. 55, no. 3, pp. 225233, 2010.

[68] J. C. Zanuncio, R. N. C. Guedes, H. N. Oliveira, and T. V. Zanuncio, "Uma década de estudos com percevejos predadores: conquistas e desafios," in Controle biológico no Brasil: Parasitóides e predadores, J. R. P. Parra, P. S. M. Botelho, B. S. CorreaFerreira, and J. M. S. Bento, Eds., pp. 495-505, Manole, São Paulo, Brazil, 2002.

[69] P. T. Cristofoletti, A. F. Ribeiro, C. Deraison, Y. Rahbé, and W. R. Terra, "Midgut adaptation and digestive enzyme distribution in a phloem feeding insect, the pea aphid Acyrthosiphon pisum," Journal of Insect Physiology, vol. 49, no. 1, pp. 11-24, 2003.

[70] M. K. Wright, S. L. Brandt, T. A. Coudron et al., "Characterization of digestive proteolytic activity in Lygus hesperus Knight (Hemiptera: Miridae)," Journal of Insect Physiology, vol. 52, no. 7, pp. 717-728, 2006.

[71] S. M. Levy, A. M. F. Falleiros, E. A. Gregório, N. R. Arrebola, and L. A. Toledo, "The larval midgut of Anticarsia gemmatalis (Hübner) (lepidoptera: Noctuidae): light and electron microscopy studies of the epithelial cells," Brazilian Journal of Biology, vol. 64, no. 3B, pp. 633-638, 2004.

[72] A. Bravo, K. Hendrickx, S. Jansens, and M. Peferoen, "Immunocytochemical analysis of specific binding of Bacillus thuringiensis insecticidal crystal proteins to lepidopteran and coleopteran mudgut membranes," Journal of Invertebrate Pathology, vol. 60, no. 3, pp. 247-253, 1992.

[73] V. M. Griego, L. J. Fancher, and K. D. Spence, "Scanning electron microscopy of the disruption of tobacco hornworm, Manduca sexta, midgut by Bacillus thuringiensis endotoxin," Journal of Invertebrate Pathology, vol. 35, no. 2, pp. 186-189, 1980.

[74] S. Mathavan, P. M. Sudha, and S. M. Pechimuthu, "Effect of Bacillus thuringiensis israelensis on the midgut cells of Bombyx mori larvae: a histopathological and histochemical study," Journal of Invertebrate Pathology, vol. 53, no. 2, pp. 217227, 1989.

[75] N. Knaak and L. M. Fiuza, "Histopathology of Anticarsia gemmatalis Hübner (Lepidoptera; Noctuidae) treated with nucleopolyhedrovirus and Bacillus thuringiensis serovar kurstaki," Brazilian Journal of Microbiology, vol. 36, no. 2, pp. 196-200, 2005.

[76] N. Knaak, A. R. Franz, G. F. Santos, and L. M. Fiuza, "Histopathology and the lethal effect of cry proteins and strains of Bacillus thuringiensis berliner in Spodoptera frugiperda J.E. Smith Caterpillars (Lepidoptera, Noctuidae)," Brazilian Journal of Biology, vol. 70, no. 3, pp. 677-684, 2010.

[77] N. Knaak, D. L. Berlitz, and L. M. Fiuza, "Toxicology of the bioinsecticides used in agricultural food production," in Histopathology: Reviews and Recent Advances, E. P. Martinez, Ed., pp. 177-194, InTech Open Access, Rijeka, Croatia, 2012.

[78] B. H. Knowles, "Mechanism of action of Bacillus thuringiensis insecticidal $\delta$-endotoxins," Advances in Insect Physiology, vol. 24, pp. 275-308, 1994.

[79] B. H. Knowles and J. A. T. Dow, "The crystal $\delta$-endotoxins of Bacillus thuringiensis: models for their mechanism of action on the insect gut," BioEssays, vol. 15, no. 7, pp. 469-476, 1993.

[80] A. Bravo, S. S. Gill, and M. Soberón, "Bacillus thuringiensis mechanisms and use," in Comprehensive Molecular Insect Science, L. I. Gilbert, I. Kostas, and S. S. Gill, Eds., pp. 175-206, Elsevier, Oxford, UK, 2005.
[81] J. Li, J. Carroll, and D. J. Ellar, "Crystal structure of insecticidal $\delta$-endotoxin from Bacillus thuringiensis at $2.5 \AA$ resolution," Nature, vol. 353, no. 6347, pp. 815-821, 1991.

[82] R. A. de Maagd, A. Bravo, and N. Crickmore, "How Bacillus thuringiensis has evolved specific toxins to colonize the insect world," Trends in Genetics, vol. 17, no. 4, pp. 193-199, 2001.

[83] L. J. Gahan, F. Gould, and D. G. Heckel, "Identification of a gene associated with Bt resistance in Heliothis virescens," Science, vol. 293, no. 5531, pp. 857-860, 2001.

[84] J. L. Jurat-Fuentes and M. J. Adang, "Characterization of a CrylAc-receptor alkaline phosphatase in susceptible and resistant Heliothis virescens larvae," European Journal of Biochemistry, vol. 271, no. 15, pp. 3127-3135, 2004.

[85] C. Hofmann, H. Vanderbruggen, H. Hofte, J. van Rie, S. Jansens, and $H$. van Mellaert, "Specificity of Bacillus thuringiensis $\delta$ endotoxins is correlated with the presence of high-affinity binding sites in the brush border membrane of target insect midguts," Proceedings of the National Academy of Sciences of the United States of America, vol. 85, no. 21, pp. 7844-7848, 1988.

[86] J. van Rie, S. Jansens, H. Höfte, D. Degheele, and H. van Mellaert, "Specificity of Bacillus thuringiensis $\delta$-endotoxins. Importance of specific receptors on the brush border membrane of the mid-gut of target insects," European Journal of Biochemistry, vol. 186, no. 1-2, pp. 239-247, 1989.

[87] I. Gómez, L. Pardo-López, C. Muñoz-Garay et al., "Role of receptor interaction in the mode of action of insecticidal Cry and Cyt toxins produced by Bacillus thuringiensis," Peptides, vol. 28, no. 1, pp. 169-173, 2007.

[88] X. Zhang, M. Candas, N. B. Griko, R. Taussig, and L. A. Bulla Jr., "A mechanism of cell death involving an adenylyl cyclase/PKA signaling pathway is induced by the CrylAb toxin of Bacillus thuringiensis," Proceedings of the National Academy of Sciences of the United States of America, vol. 103, no. 26, pp. 9897-9902, 2006.

[89] J. Oestergaard, R. Ehlers, A. C. Martínez-Ramírez, and M. D. Real, "Binding of Cyt1Aa and CryllAa toxins of Bacillus thuringiensis serovar israelensis to brush border membrane vesicles of Tipula paludosa (Diptera: Nematocera) and subsequent pore formation," Applied and Environmental Microbiology, vol. 73, no. 11, pp. 3623-3629, 2007.

[90] M. E. C. Sousa, F. A. B. Santos, V. Wanderley-Teixeira et al., "Histopathology and ultrastructure of midgut of Alabama argillacea (Hübner) (Lepidoptera: Noctuidae) fed Bt-cotton," Journal of Insect Physiology, vol. 56, no. 12, pp. 1913-1919, 2010.

[91] Y. C. Zhu, F. R. Zeng, and B. Oppert, "Molecular cloning of trypsin-like cDNAs and comparison of proteinase activities in the salivary glands and gut of the tarnished plant bug Lygus lineolaris (Heteroptera: Miridae)," Insect Biochemistry and Molecular Biology, vol. 33, no. 9, pp. 889-899, 2003.

[92] B. A. M. Guedes, J. C. Zanuncio, F. S. Ramalho, and J. E. Serrão, "Midgut morphology and enzymes of the obligate zoophytophagous stinkbug Brontocoris tabidus (Signoret, 1863) (Heteroptera: Pentatomidae)," Pan-Pacific Entomologist, vol. 83, no. 1, pp. 66-74, 2007.

[93] D. Hegedus, M. Erlandson, C. Gillott, and U. Toprak, "New insights into peritrophic matrix synthesis, architecture, and function," Annual Review of Entomology, vol. 54, pp. 285-302, 2009.

[94] P. E. Degrande and L. M. Vivan, "Pragas da soja," in Boletim de Pesquisa de Soja, J. Caju, M. M. Yuyama, S. Suzuki, and S. A. Camacho, Eds., vol. 12, p. 254, Fundação MT, Rondonópolis, Brazil, 2008. 
[95] A. Chattopadhyay, N. B. Bhatnagar, and R. Bhatnagar, "Bacterial insecticidal toxins," Critical Reviews in Microbiology, vol. 30, no. 1, pp. 33-54, 2004.

[96] E. W. Nester, L. S. Thomashow, M. Metz, and M. Girdon, 100 Years of Bacillus thuringiensis: A Critical Scientific Assesment, ASM, Washington, DC, USA, 2002.

[97] P. Tamez-Guerra, L. J. Galán-Wong, H. Medrado-Roldán et al., "Bioinsecticidas: su empleo, producción y comercialización em México," Ciência UANL, San Nicolás de Los Garzas, vol. 4, no. 2, pp. 143-152, 2001.

[98] M. Chen, J. Zhao, H. L. Collins, E. D. Earle, J. Cão, and A. M. Shelton, "A critical assessment of the effects of Bt transgenic plants on parasitoids," PLoS ONE, vol. 3, no. 5, Article ID e2284, 2008.

[99] J.D. Vendramim and E.C. Guzzo, "Resistência de plantas e a bioecologia e nutrição dos insetos," in Bioecologia e nutrição de insetos: base para o manejo integrado de pragas, A. R. Panizzi and J. R. P. Parra, Eds., pp. 1055-1105, Embrapa Informação Tecnológica, Brasília, Brazil, 2009.

[100] J. O. Siqueira, I. C. B. Trannin, M. A. P. Ramalho, and E. M. G. Fontes, "Interferências no agrossistema e riscos ambientais de culturas transgênicas tolerantes a herbicidas e protegidas contra insetos," Cadernos de Ciência \& Tecnologia, vol. 21, pp. 11-81, 2004.

[101] M. Marvier, C. McCreedy, J. Regetz, and P. Kareiva, "A metaanalysis of effects of Bt cotton and maize on nontarget invertebrates," Science, vol. 316, no. 5830, pp. 1475-1477, 2007.

[102] C. James, Global Status of Commercialized Biotech/GM Crops: 2009, ISAAA Brief No. 41, ISAAA, Ithaca, NY, USA, 2009.

[103] A. L. Boiça Jr., A. G. da Silva, D. B. Bottega et al., "Resistência de plantas e o uso de produtos naturais como táticas de controle no manejo integrado de pragas," in Tópicos em Entomologia Agrícola-IV, A. C. Busoli, D. F. Fraga, L. da Conceição-Santos et al., Eds., pp. 139-158, Gráfica Multipress Ltda, Jaboticabal, Brazil, 2011.

[104] P. Christou, D. E. McCabe, and W. F. Swain, "Stable transformation of soybean callus by DNA-coated gold particles," Plant Physiology, vol. 87, no. 3, pp. 671-674, 1988.

[105] M. A. W. Hinchee, D. V. Connor-Ward, C. A. Newell et al., "Production of transgenic soybean plants using Agrobacteriummediated DNA transfer," Biotechnology, vol. 6, no. 8, pp. 915922, 1988.

[106] N. Crickmore, "Beyond the spore-past and future developments of Bacillus thuringiensis as a biopesticide," Journal of Applied Microbiology, vol. 101, no. 3, pp. 616-619, 2006.

[107] D. G. Heckel, L. J. Gahan, S. W. Baxter et al., "The diversity of Bt resistance genes in species of Lepidoptera," Journal of Invertebrate Pathology, vol. 95, no. 3, pp. 192-197, 2007.

[108] J. L. Fox, "Resistance to Bt toxin surprisingly absent from pests," Nature biotechnology, vol. 21, no. 9, pp. 958-959, 2003.

[109] D. R. G. Price and J. A. Gatehouse, "RNAi-mediated crop protection against insects," Trends in Biotechnology, vol. 26, no. 7, pp. 393-400, 2008. 

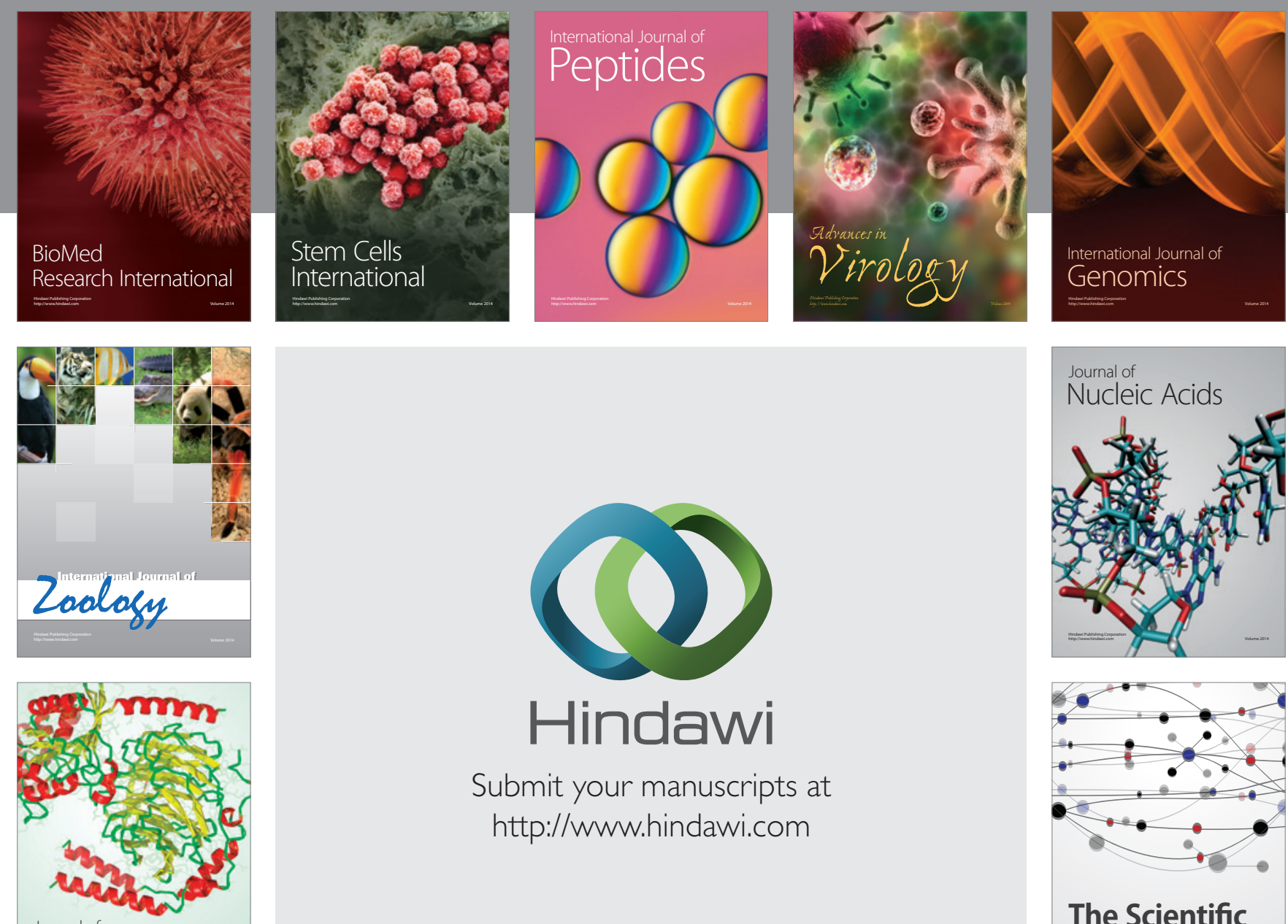

Submit your manuscripts at

http://www.hindawi.com

Journal of
Signal Transduction
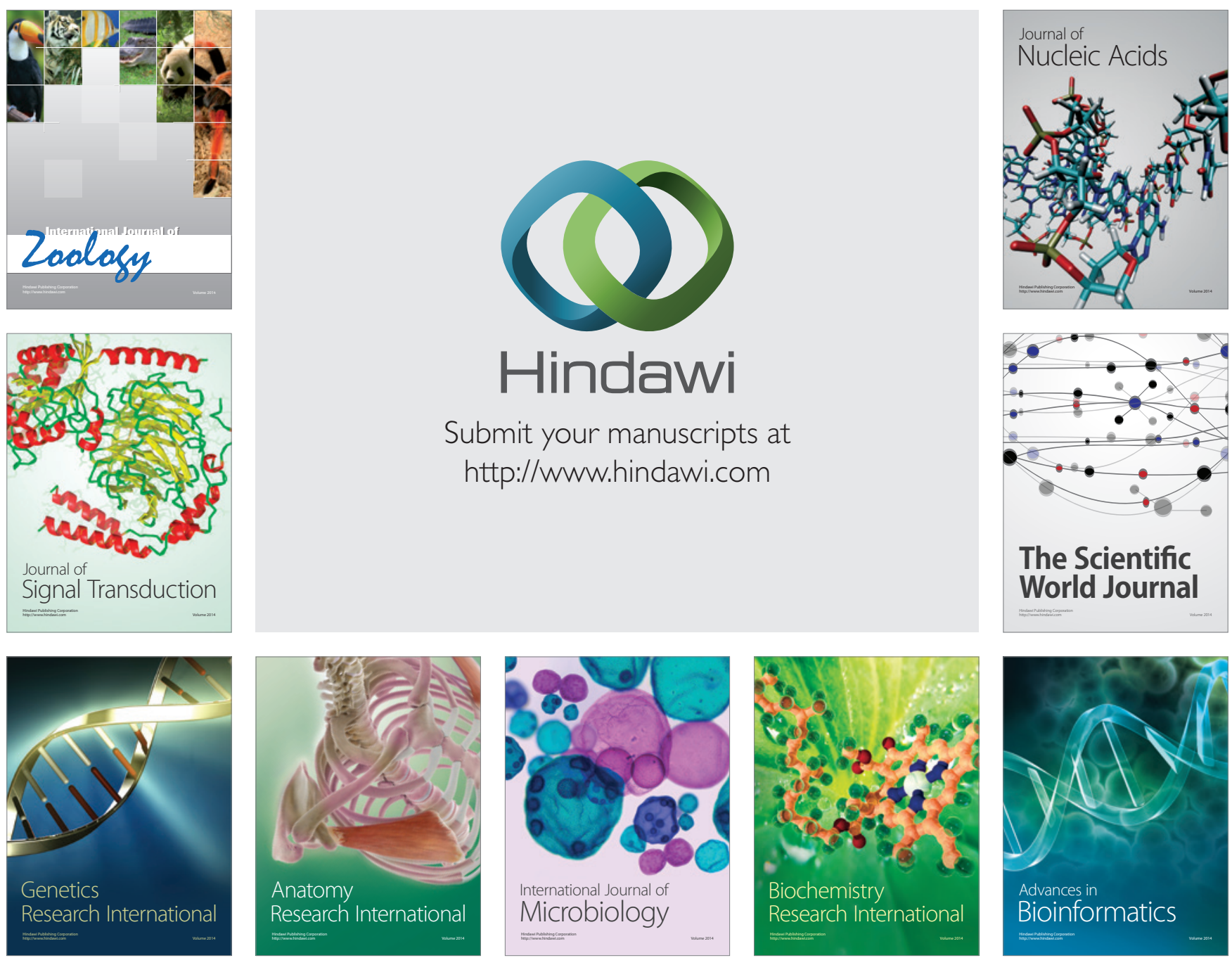

The Scientific World Journal
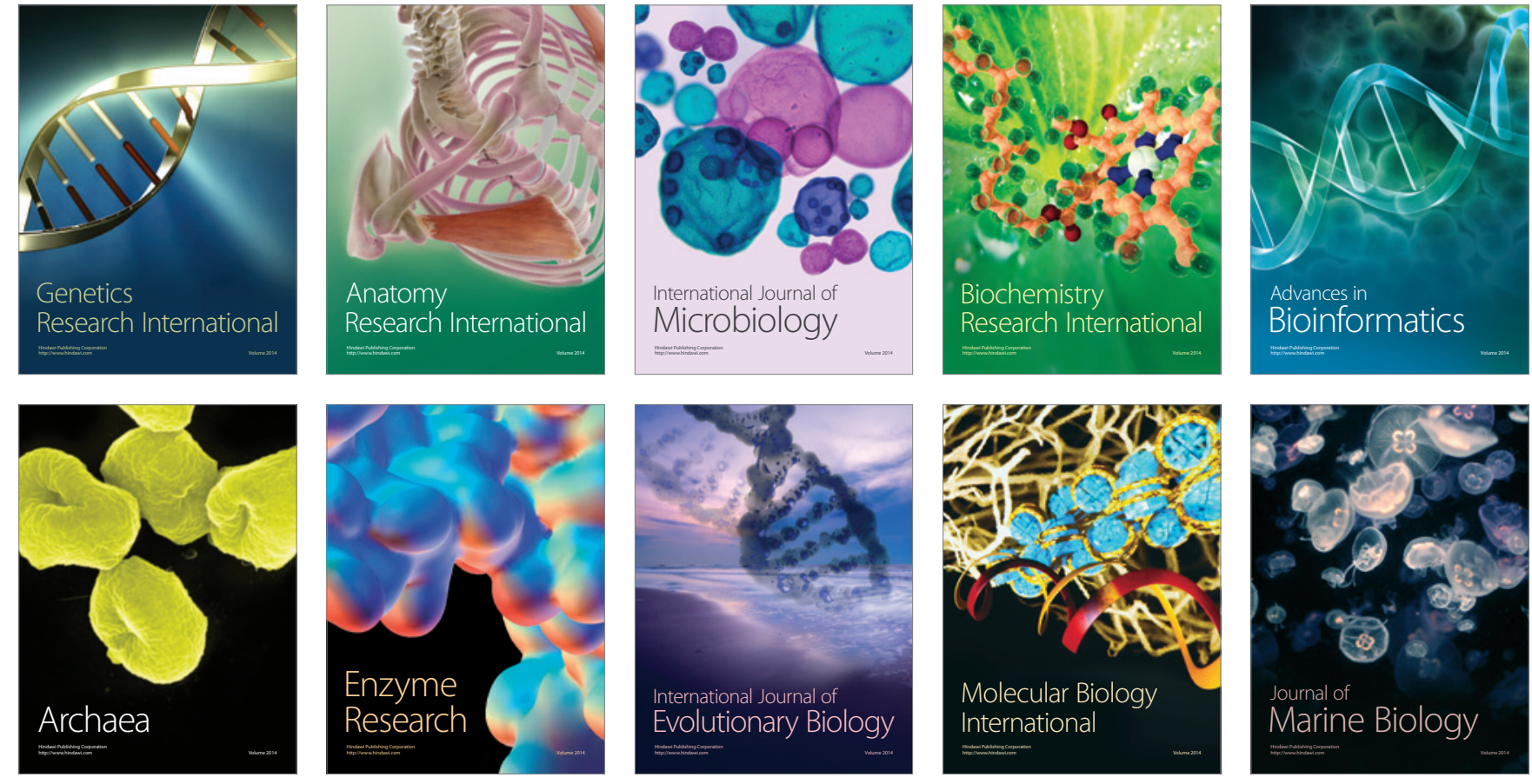